\title{
Impact of Industry 4.0 on Occupations and Employment in Turkey
}

\author{
Beyza Sumer, (Asst. Prof. Dr.) \\ Department of Economics, Faculty of Business \\ Dokuz Eylül University, Turkey
}

Doi: 10.19044/esj.2018.v14n10p1 $\quad$ URL:http://dx.doi.org/10.19044/esj.2018.v14n10p1

\begin{abstract}
New technologies of this age is widely referred as Industry 4.0. The rapid increase in digitalization, robotization, and intelligent automation has great impact on markets, including the labour market. Technological changes destroy some jobs while generating new jobs and occupations. Replacement of jobs by robots, smart vehicles, digitalized and connected processes will have great impact on labour market resulting in mass unemployment. This paper aims to highlight prospective changes in occupations and job losses due to new technologies in Turkey. Following the introduction part, the paper proceeds to literature review about the effect of new technologies on jobs, skills, tasks, occupations, and employment. In the next part, a time analysis of occupations in Turkey takes place in order to bring out the occupations which might be substituted by Industry 4.0, and thus might result in mass unemployment. A framework for susbstitutable and complementable occupations in Turkey has been constituted in this part, too. In the concluding remarks, it has been put forward that there will be considerable losses in some occupational categories with routine tasks, both in manual and cognitive jobs. In some other jobs, new technologies have a complementing effect which might lead to employment generation. It has been suggested that Turkey can get the better of negative impacts of Industry 4.0 by fully analysing the issue, improving training and skills upgrading, and promoting jobs in technology and creativity related new fields such as cultural and creative industries.
\end{abstract}

Keywords: Industry 4.0, technology, jobs, occupations, employment

\section{Introduction}

Technology has always changed and transformed the structure and composition of the economy, including the labour market, and has substituted many jobs leaving numerous working people vulnerable. Sophisticated mechanization, robotization, automation and digitalization have served to the 
reduction of labour costs. In addition, the socio-economic impact of new technologies has perpetuated inequalities further.

Advanced technologies aim to reduce the costs and the risks that arise during production of goods and services, and they demand more sophisticated skills. On one hand, new jobs are created; on the other hand, some jobs become extinct due to the provision of new technologies. All this leads to a significant change in the structure and composition of the whole economy.

The new technology and its various facets have been referred to as 'Industry 4.0' after Germany launched a project to digitalize manufacturing at the Hannover Messe in 2011. Since then the term "Industry 4.0" has started to be used widely. Some call it 'Economy 4.0' and some refer to it as ' 4 th Wave Industrial Revolution' within the context that Industry 1.0 meant the technology brought about by the Industrial Revolution; Industry 2.0 implied the Fordist Mass Production in the first decades of the 1900's; Industry 3.0 was the period where computerisation plus robotic automation were used in the 1990's. And now Industry 4.0 is the fourth wave of technological advancement.

Industry 4.0 implies cyber-physical systems monitoring the physical processes and making decisions with the aim of increasing output and productivity, and of reducing costs and risks arising during production in the industrial sector. Besides manufacturing, it is being used in various fields of services sector such as transportation, health, creative industries, etc. Various applications of Industry 4.0 as of sophisticated, smart, and mobile robots, interrelation of robots and machines (machine learning), cyber- physical and inter-connectedness of systems (internet of things), machines and systems empowered by computer softwares and their autonomous functioning (artificial intelligence), connecting and adding the real to the virtual (augmented reality) have started to increase rapidly.

This paper aims to highlight prospective changes in job losses and employment in Turkey due to the new technologies, and tries to constitute a framework for further analysis to be made by researchers. The methodology of the paper is hypothetical supported by empirical data which is obtained from the Turkish Institute of Statistics (TUIK), Household Labour Force Surveys, from 2001 to 2017 January. This study's shortcomings fundamentally results from the broad scope of the topic itself. In fact, the issue needs an elaborative analysis of thousands of jobs and occupations with skills and tasks associated with them. Nonetheless, this paper might be helpful for other researchers by shedding light on the matter and constituting a framework for further analysis.

After the introduction part, the paper proceeds to literature review about the effect of new technologies on jobs, skills, tasks, occupations, and employment. In the following part, a time analysis of occupations in Turkey 
takes place. In the concluding remarks, it has been stated that there will be considerable losses in occupations that have routine tasks, both in manual and cognitive jobs. It is suggested that Turkey can come over this phenomenal fact of Industry 4.0 by focusing on training and skills upgrading in line with technological changes, and promoting jobs in new fields such as cultural and creative industries.

\section{Effect of New Technologies on Labour Market Outcomes}

Extensive use of automation, robotization, computerization and digitalization have serious effects on jobs, skills, and occupations. The impacts of technology on labour market have been studied notably within the context of job losses/ job gains and employment destruction/ employment generation.

A considerable number of researchers have examined the effect of technology on jobs and skills and have concluded that technology complements skilled labor, and generates 'skill bifurcation', raising the level of skills in complex jobs whereas deskilling the low-skilled jobs, and eventually creating a bias towards skilled labor in developed countries (Acemoglu, 1998; Autor et al., 1998; Ben-Ner and Urtasun, 2013; Bresnahan and Greenstein, 1999). It has been underlined that skill-biased technological change leads to a qualitative change in the jobs by the increase in demand for skills. Hence, technological change increases demand for skilled and educated workers (Golden and Katz, 2007).

The growth of low-skilled jobs on one hand, and the demand for highskilled jobs on the other hand have led to a job polarization in the labour market, particularly in the USA (Autor and Dorn, 2009, 2010, 2013; Acemoglu and Autor, 2012). Job polarization occurs between high-skilled and high-wage occupations and low-skilled and low-wage occupations (Acemoglu, 1999). This in turn leads to wage inequality and unemployment of the non-skilled employee. A group of researchers have examined the impact of technology on the educational wage differentials in the USA and they have found that skill upgrading has been greater in computer-intensive industries (Autor et al., 1998).

In connection with job polarization, a comprehensive analysis was made to see the changes in the occupational structure in the USA. A considerable amount of jobs, 318 occupations, was taken and ranked by their skill levels from the lowest to the highest. The study showed that a substantial increase occurred in the low-education and low-wage occupations starting in the 1990's and escalated thereafter. They put forward that there was a significant decline in real wages of low-skilled workers; and an increase in employment in both high- and low-skilled occupations relative to middleskilled occupations. They added that the rapid use of new technologies take 
over and fulfill the tasks which are performed by middle-skilled workers. They claimed that job or employment polarization was not unique to the USA and seen in the EU countries also (Acemoglu and Autor, 2011).

There are noteworthy analyses about the impact of technology in other developed economies. The use of new technologies have been found to increase the transition from employment to unemployment in France. The results show that the rate of job loss is significantly higher in industries which have the largest share of R\&D and other new technologies' users (Givord and Maurin, 2004). Another research studied the technical change, skills, jobs, and wages in West Germany. It has been concluded that occupations require more complex skills today than in 1979, and that the changes in skill requirements have been more demanded in computerizing occupations (SpitzOener, 2006).

The skill-biased technological change hypothesis seems to disregard the existence of middle-skilled workers. A different approach is proposed by Autor et al.(2003) who focused on tasks rather than wages or employment. They studied the sources of job polarization and put forward the substituting and complementing effects of 'computer capital'. They stated that 'computer capital' substitutes workers who perform a limited and well-defined tasks which are called routine tasks. In other words, computers can easily perform those routine tasks. They added that 'computer capital' complements workers who carry out activities that require creativity, problem solving, and communication skills which are not limited and not well-defined. They are called non-routine tasks, and they cannot be substituted by digital technologies.

Those routine tasks exist in many middle-skilled office, clerical, and assembly jobs. Indeed, swingeing declines in clerical occupations seem to be a consequence of the new technologies substituting these tasks. The 'routinization' hypothesis suggests that new technologies will replace routine labor that has middle level skills and income.

Having said that, the process of routinization may occur both in lowand high-skilled jobs. The new technologies may complement or substitute both low or high-skilled workers (Acemoglu and Autor, 2011; Behaghel et al., 2011). Therefore it would be elucidatory to mention various particularities of routine and non-routine tasks.

Routine and non-routine tasks are divided into two categories, abstract/cognitive and manual tasks. Both routine and non-routine tasks can be abstract or manual. Abstract tasks which are also referred as cognitive or analytical tasks require problem solving, judgement, creativity, analytical and abstraction skills. The analytical tasks do not need in-person interactions. Some examples for such occupations are engineers, mathematicians, designers. However some cognitive jobs might require complex interpersonal 
interactions, such as attorneys, scientists, and managers, doctors. Some abstract tasks include routine tasks, as in bookkeeping. Interpersonal jobs which require in-person interaction can be manual or cognitive. These jobs, be manual or cognitive, cannot be automated due to this particularity. Manual tasks require situational and/or environmental adaptability, visual and/or language recognition, and in-person interactions. Some jobs that include such tasks are beauty and health workers, home aides, construction laborers, salespersons, security personnel, and motor vehicle operators (Acemoglu and Autor, 2011; Autor and Dorn, 2009).

The occupations and tasks which cannot be automated, at least for now, are non-routine cognitive/analytical and non-routine manual and interpersonal ones (Fonseca et al., 2013). These jobs are less susceptible to substitution by new technologies due to the demand for problem solving, judgement, creativity, in-person interactivity, flexibility, and environmental adaptability (Autor and Dorn, 2009).

Chart 1: Characteristics of Occupational Tasks

\begin{tabular}{|c|c|c|}
\hline Tasks & Routine & Non-routine \\
\hline Cognitive/ abstract & $\begin{array}{c}\text { - librarians } \\
\text {-keyboard clerks }\end{array}$ & $\begin{array}{c}\text {-managers } \\
\text {-artistic professionals } \\
\text {-scientists }\end{array}$ \\
\hline Manual & $\begin{array}{c}\text {-plant assemblers } \\
\text {-medical technicians }\end{array}$ & $\begin{array}{c}\text {-beauticians } \\
\text {-plumbers } \\
\text {-health aides }\end{array}$ \\
\hline
\end{tabular}

Source: Autor and Dorn (2009); Acemoglu and Autor (2011).

What impact digital and smart technologies would have on labour market outcomes is a hot topic on the agenda of many researchers and policy makers. Frey and Osborne (2013), who have been referred by numerous researchers, examined the impact of future computerisation on the US labour market, with the aim of predicting the number of jobs at risk. They estimated the probability of computerisation for 702 detailed occupations. According to their findings, about 47 percent of total US employment is claimed to be at risk.

The researchers provided evidence that wages and educational levels show a strong negative relationship with an occupation's probability of computerisation; and they added that computerisation enters into more cognitive domains, too. They refered to the estimates by McKinsey Global Institute who suggests that 'sophisticated algorithms' can substitute for about 140 million full-time knowledge workers worldwide.

For the EU countries, a particular research which includes sixteen European countries, covering the period of 1993-2010 has been conducted to exhibit the phenomena of polarization and routinization (Goos et al., 2009). The researchers found a distinct pattern of polarization with an increase in high-paying and low-paying occupations, and a decrease in medium-paying 
occupations in Europe. The increase in high-paying jobs was seen mostly in professionals and managers; and the increase in low-paying jobs was seen in personal services, transport, and sales workers. The decrease was seen in medium-paying jobs such as craft workers, machine operators, and office clerks. The average decline in medium-paying, middle- skilled jobs across the countries was 8 percent. In 13 of total 16 countries, high wage occupations increased their share of employment with 6 percent. In the all 16 countries, low wage occupations increased in size relative to middle wage occupations with 10 percentage points.

Other results focusing on job generation can also be seen in the literature. In a recent report (Boston Consulting Group, 2015), it has been studied how the introduction of digital industrial technologies will affect the evolution of 40 job families in 23 industries in Germany. It is forecasted that 610,000 jobs will be lost in assembly and production, but 960,000 jobs will be created particularly in information technologies. Hence, the report concludes that there will be an increase of 350,000 jobs in Germany through 2025.

In Germany, a prominent project named 'The QuBe' is being run under the joint leadership of the Federal Institute for Vocational Education and Training (BIBB) and the Institute for Labour Market and Career Research $(\mathrm{IAB})^{1}$. The project provides the probable development of labour demand and supply in terms of qualifications and occupations. According to IAB's employment research (2016), Economy 4.0 will increase the size of jobs in services. This research examined 15 occupational fields out of 50 occupational fields which were mainly from the manufacturing industry. The exception was the 'occupational field 33', namely 'finance, accounting, bookkeeping' which was affected the most along with the occupations in the manufacturing industry.

At an industry level, 320,000 jobs will be lost in 2025 compared to the QuBe baseline projection, while about 290,000 additional jobs will be created by 2025 . With respect to the occupational fields, about 1.22 million jobs total will be lost and on the other hand 1.19 million jobs will be created in different fields by 2025 .

The last but not the least, an issue needs to be mentioned here. In a study about the off-shored jobs, it is argued that any job which does not need in-person interactions can ultimately be outsourced regardless of whether its primary tasks are abstract, routine, or manual. The researchers (Blinder and Krueger, 2009; 2013) found that about $25 \%$ of the US jobs were off-shorable. Susceptibility of Occupations to New Technologies in Turkey

\footnotetext{
${ }^{1}$ It is carried out in collaboration with the Institute of Economic Structures Research (GWS) and the Fraunhofer Institute for Applied Information Technology (FIT), Germany.
} 
In this section, I tried to analyze the prospective trend in occupations in the Turkish labour market in order to highlight the susceptibilities of some occupations and jobs to new technologies on one hand, and to bring forward the advantages in some occupations which might be enhanced and augmented by the use of new technologies on other hand.

ILO has classified jobs and occupations according to the tasks and duties undertaken in the jobs; and those tasks and duties are correlated with the skills and education levels of the working people (1). This classification is called the International Standard Classification of Occupations, ISCO 88 which is composed of nine major categories: (1) legislators, senior officials, and managers; (2) professionals; (3) technicians, and associate professionals; (4) clerks; (5) service workers, and shop and market workers; (6) skilled agricultural and fishery workers; (7) craft and related trades workers; (8) plant and machine operators and assemblers; (9) elementary occupations.

In the paper, I used both the main categories (with 1-digit) and the sub-categories (with 3-digits). For example, the main category ' 4 ' denotes the group of 'clerks', '43' stands for 'numerical and material recording clerks', and ' 431 ' is 'numerical clerks'.

In this analysis, I didn't include the $9^{\text {th }}$ category, the "elementary occupations" because this category has always been the most vulnerable one in every sense, whether by the new technologies or other means. The subcategories of this group are cleaners and helpers (91), agricultural, forestry and fishery labourers (92), labourers in mining, construction, manufacturing and transport (93), food preparation assistants (94), street and related sales and services workers (95), refuse workers and other elementary workers (96). This occupational category has the lowest educational attainments, skills, and income levels. Some of these elementary jobs can be affected negatively by new technologies such vehicle, window, laundry and other hand cleaning workers (912), manufacturing labourers (932), transport and storage labourers (933). On the other hand, some of the jobs will not be substituted by robots or digital technologies because the tasks that these occupations perform are quite trivial to be replaced by robots or machines. The jobs in this category should be evaluated according to the technological capital used in this group. In other words, if technological capital is not directed to that specific occupation/job, then there won't be any grounds for substitution effect by new technologies. In Turkey, the number of workers in this category increased greatly during the reference period 2001-2017. It was 1.84 million in 2001; reached to its highest level of 4.16 million in 2016; then it fell to 3.66 million in 2017.

As specified before, all occupations can be broadly grouped as routine or non-routine, and cognitive or manual. Routine tasks encompass standardized, limited, well-defined set of both cognitive and manual tasks; 
non-routine tasks don't include standardized tasks. Cognitive (or abstract) tasks demand problem solving, judgement, creativity, and/or complex inperson interactions; manual tasks require situational adaptability, visual and/or language recognition, and in-person interactions (Acemoglu and Autor, 2011; Autor and Dorn, 2009; Autor et al, 2003).

According to these characteristics, 'non-routine and manual', and 'non-routine and cognitive (or abstract)' occupations will not be susceptible to digitalization, robotization, and automation, at least not in the near future. New technologies will complement these non-routine tasks.

However, 'routine and cognitive (or abstract)', and 'routine and manual' jobs will be rapidly substituted by new technologies. It can be deduced that all routine jobs, whether cognitive or manual are substitutable by new technologies. This susceptibility will eventually lead to a rapid increase in unemployment rates.

In light of the above characterization of the tasks, I analysed the main categories and subcategories of occupations by using the least squares method. For the analysis, I used the number of people working in five main categories in a time series from 2001 up to 2017 January. The data used in the paper are obtained from the Turkish Statistics Department, Household Labour Surveys.

The total number of people working at all occupations was 21.5 million in 2001 and reached to 26.7 million in 2007 January. Any increase in the number of the occupations which are substitutable by new technologies will lead to high rates of unemployment in that category. If the increase in the occupation category is slight, then unemployment in that category might be slight. Any decrease in the number of occupations which are substitutable by new technologies will not lead to technological unemployment. The assumptions and the findings about occupations in Turkey are as below:

(A) Technicians and Associate Professionals ( $3^{\text {rd }}$ category) include subcategories of science and engineering associate professionals (31), health associate professionals (32), business and administration associate professionals (33), legal, social, cultural and related associate professionals (34), and information and communications technicians (35).

In the $3^{\text {rd }}$ category, some of the occupations can be substituted (replaced) and some of them can be complemented by new technologies. For example, financial and mathematical associate professionals (331), process control technicians (313), medical and pharmaceutical technicians (321) can be replaced by new technologies due to the routine tasks they perform. On the other hand, ship and aircraft controllers and technicians (315), nursing and midwifery associate professionals (322), traditional and complementary medicine associate professionals (323), sales and purchasing agents and brokers (332), artistic, cultural and culinary associate professionals (343) will 
probably be complemented by digital technologies because of the situational adaptability and in-person interactions that the tasks of these occupations require.

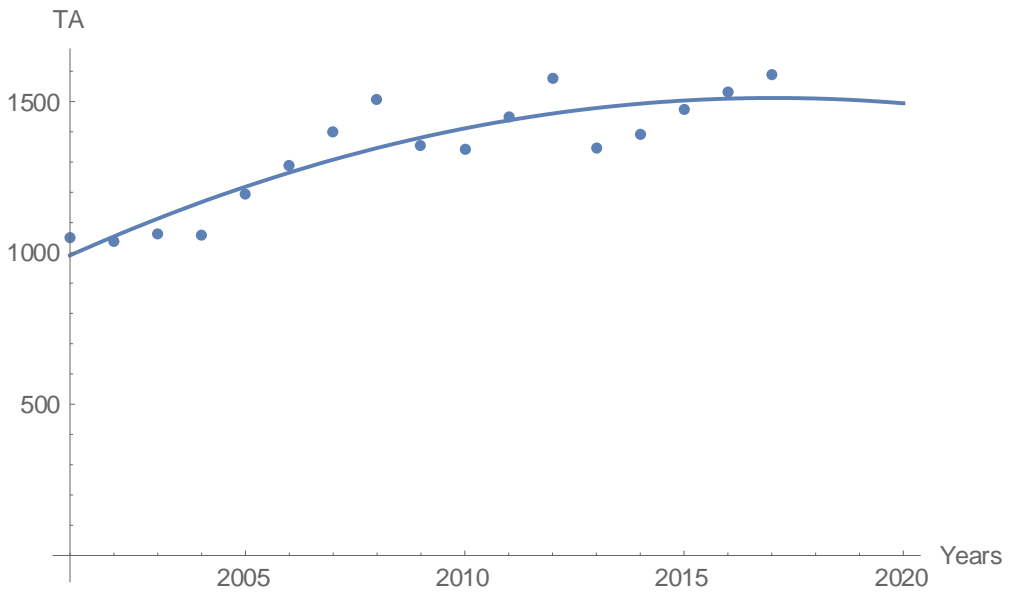

Figure 1: The number of technicians, and associate professionals (TA) in Turkey, in thousands, polynomial, $\mathrm{R}=0.811$

Source: Author's calculation, data from Turkish Institute of Statistics (TUIK), Household Labour Surveys, 2001-2017 January.

In Turkey, a moderate increase occurred in 2008 (1.51 million). After 2008 , it increased slightly and reached to 1.59 million in 2017 . This category is regarded as highly susceptible to digitalization. However, there will not be mass unemployment in this category because of the slight increase in the number of occupations. Nevertheless, necessary measures have to be taken for this category also.

(B) Clerical Support Workers ( $4^{\text {th }}$ category) include subcategories of general and keyboard clerks (41), customer services clerks (42), numerical and material recording clerks (43), and other clerical support workers (44). Most of the clerical occupations are susceptible to digitalization. Secretaries (412), keyboard operators (413), tellers and money collectors (421), numerical clerks (431), material recording and transport clerks (432) will be substituted via automation and digitalization. Some of the client information workers (422) which require situational adaptability and in-person interactions might not be substituted by new technologies. 


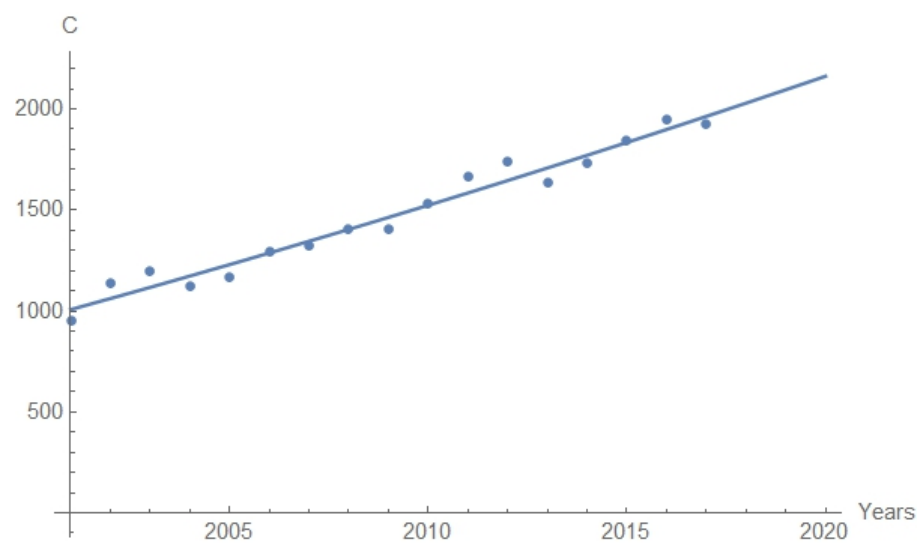

Figure 2: The number of clerks (C) in Turkey, in thousands, polynomial, $\mathrm{R}=0.966$ Source: Author's calculation, data from Turkish Institute of Statistics (TUIK), Household Labour Surveys, 2001-2017 January.

In Turkey, a substantial increase occurred in this category in ten years. It was 1.32 million in 2007 and went up to 1.93 million in 2017. Any increase in this category, which is highly substitutable by new technologies, may end up with mass unemployment. This group is one of the most vulnerable groups which needs new job trainings and/or upgradings in order to cope with the challenges brought about by new technologies.

(C) Services and Sales Workers ( $5^{\text {th }}$ category) encompass mostly nonroutine jobs and occupations with high in-person interactions and situational adaptability. This category includes personal services workers (51), sales workers (52), personal care workers (53), protective services workers (54).

The non-routine tasks demanded by these occupations imply that they cannot be substituted by robots or digital technologies (such as cooks (512), hairdressers, beauticians and related workers (514)).However, some of the services and sales jobs, such as conductors (511) -but not guides (511), shop salespersons (522), and cashiers and ticket clerks (523), can and will easily be substituted by robots and digital means. 


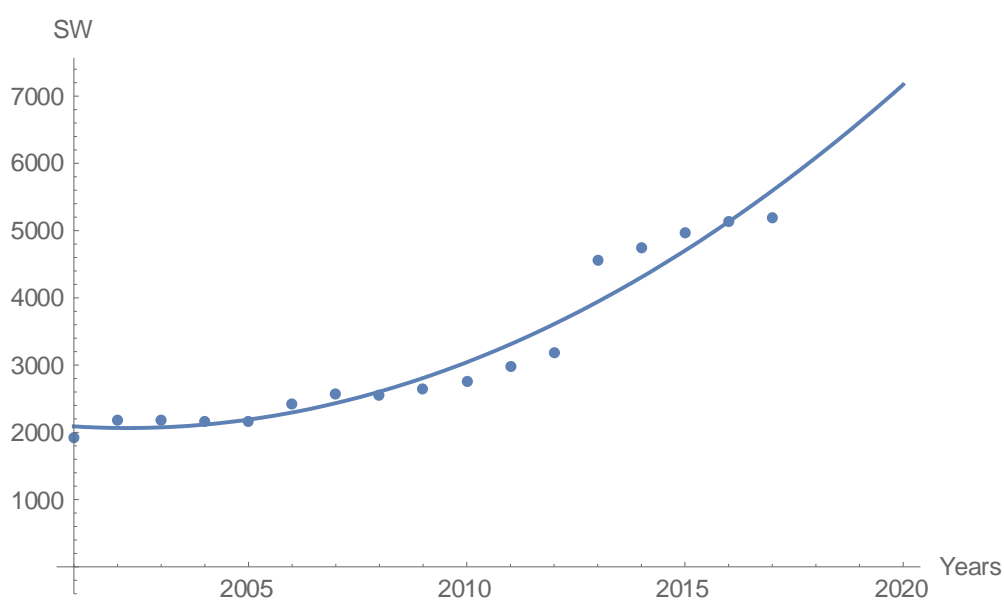

Figure 3: The number of service, and shop and market sales workers (SW) in

Turkey, in thousands, polynomial, $\mathrm{R}=0.943$

Source: Author's calculation, data from Turkish Institute of Statistics (TUIK), Household Labour Surveys, 2001-2017 January.

A very rapid increase is witnessed in this category in Turkey. The number of workers in this category was 2.57 million in 2007 and went up to 5.19 million in 2017. The low-paid and substitutable subcategories of this group will face difficulties by the intense use of digital technologies. The increase in the number of occupations in this category implies that there is the danger of mass unemployment for the substitutable jobs in this category.

(D) Plant and Machine Operators and Assemblers ( $8^{\text {th }}$ category) include subcategories of stationary plant and machine operators (81), assemblers (82), drivers and mobile plant operators (83). Most of the sub-categories of this group are highly susceptible to robotization, automation, and digitalization.

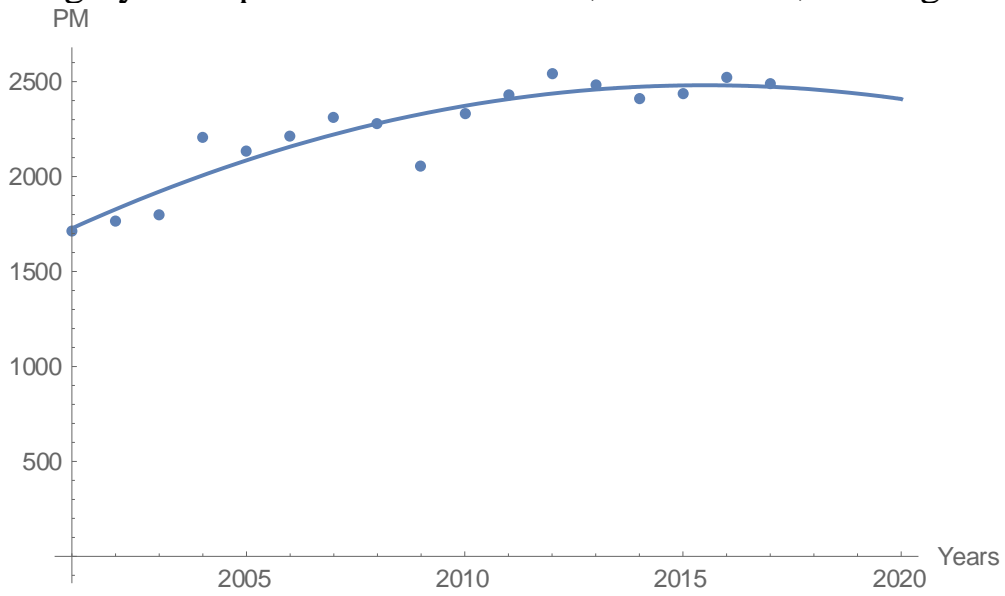

Figure 4: The number of plant and machine operators and assemblers (PM) in

Turkey, in thousands, polynomial, $\mathrm{R}=0.856$

Source: Author's calculation, data from Turkish Institute of Statistics (TUIK), Household Labour Surveys, 2001-2017 January. 
The number of people in this category did not change much in Turkey. It was 2.31 million in 2007 and became 2.49 million in 2017. This slight increase implies that mass unemployment might not happen in this category. However, this group is the most vulnerable one due to its high substitutability by automated machines, robots, digital means, and intelligent vehicles. Therefore, specific measures have to be taken for this category, too.

Chart 2: Occupations Substitutable by New Technologies in Turkey, by 3 digits

Source: categorized by the author.

\begin{tabular}{|c|c|}
\hline Tasks & Routine \\
\hline cognitive/ abstract & $\begin{array}{c}\text { 311- physical and engineering science technicians } \\
\text { 331- financial and mathematical associate professionals } \\
\text { 332- sales and purchasing agents and brokers } \\
\text { 411- general office clerks } \\
\text { 412- secretaries (general) } \\
\text { 431- numerical clerks } \\
\text { 432- material recording and transport clerks } \\
\text { 441- other clerical support workers }\end{array}$ \\
\hline manua/face-to-face & $\begin{array}{c}\text { 312- mining, manufacturing and construction supervisors } \\
\text { 313- process control technicians } \\
\text { 321- medical and pharmaceutical technicians } \\
\text { 413- keyboard operators } \\
\text { 511- travel attendants, conductors and guides* } \\
\text { 522- shop salespersons } \\
\text { 523- cashiers and ticket clerks } \\
\text { 812- metal processing and finishing plant operators } \\
\text { 813- chemical and photographic products plant and machine } \\
\text { operators } \\
\text { 814- rubber, plastic and paper products machine operators } \\
\text { 815- textile, fur and leather products machine operators** } \\
\text { 816- food and related products machine operators } \\
\text { 817- wood processing and papermaking plant operators } \\
\text { 818- other stationary plant and machine operators } \\
\text { 821- assemblers } \\
\text { 831- locomotive engine drivers and related workers*** } \\
\text { 832- car, van and motorcycle drivers*** } \\
\text { 833- heavy truck and bus drivers*** } \\
\text { 834- mobile plant operators**** }\end{array}$ \\
\hline
\end{tabular}

* guides excluded; ** some of the processes of this subcategory might not be substitutable but complementable by new technologies; *** driverless vehicles might be launched in the near future; **** some of them can be replaced by intelligent vehicles while some will not be replaced due to the complexity of the task.

Routine jobs that are susceptible to technological change do not imply that all routine jobs will be replaced by robots and digital devices right away. Some occupations under the following sub-categories may not be susceptible to technology. On the other hand, some of the non-routine jobs which are not substitutable by new technologies for the time being can be substituted by 
new technologies in the foreseeable future. For that reason, the examples below should be assessed and taken into consideration cautiously.

Chart 3: Occupations Complementable by New Technologies in Turkey, by 3 digits

\begin{tabular}{|c|c|}
\hline Tasks & Non-routine \\
\hline cognitive/ abstract & $\begin{array}{c}\text { 314- life science technicians and related associate } \\
\text { professionals } \\
\text { 315- ship and aircraft controllers and technicians } \\
\text { 351- information and communications technology operations } \\
\text { and user support technicians* } \\
\text { 352- telecommunications and broadcasting technicians* }\end{array}$ \\
\hline manual/face-to-face & $\begin{array}{c}\text { 322- nursing and midwifery associate professionals } \\
\text { 323- traditional and complementary medicine associate } \\
\text { professionals } \\
\text { 324- veterinary technicians and assistants } \\
\text { 325- other health associate professionals } \\
\text { 333- business services agents } \\
\text { 334- administrative and specialized secretaries } \\
\text { 335- government regulatory associate professionals } \\
\text { 341- legal, social and religious associate professionals } \\
\text { 342- sports and fitness workers } \\
\text { 343- artistic, cultural and culinary associate professionals } \\
\text { 421- tellers, money collectors and related clerks } \\
\text { 422- client information workers** } \\
\text { 512- cooks } \\
\text { 513- waiters and bartenders } \\
\text { 514- hairdressers, beauticians and related workers } \\
\text { 515- building and housekeeping supervisors } \\
\text { 516- other personal service workers } \\
\text { 521- street and market salespersons } \\
\text { 524- other sales workers } \\
\text { 531- child care workers and teachers' aides } \\
\text { 532- personal care workers in health services } \\
\text { 541- protective services workers } \\
\text { 811- mining and mineral processing plant operators } \\
\text { 835- deck crews and related workers }\end{array}$ \\
\hline
\end{tabular}

Source: author's categorization.

* some of these occupational subcategories may decrease due to increasing use of new technologies; ** some of the subcategories of this group can easily be replaced by new technologies, such as telephone switchboard operators (4223).

\section{Concluding Remarks}

In this paper, I tried to highlight probable vulnerabilities and disadvantages that some occupations might face due to the ongoing skillbiased technological change in Turkey. By analysing the four categories of occupations in a time series (2000-2017), I deduced that any prospective increase in the number of occupations with routine tasks will be substituted by new technologies and eventually will result in mass unemployment. 
The extent of the jobs and occupations that might be substituted depends on the routine and non-routine tasks they they require. In some occupational groups, a limited amount of jobs might be replaced; yet in other groups a vast amount of jobs might be substituted.

The first, second, sixth, and seventh categories are not taken into consideration in this paper because these occupations include non-routine and cognitive tasks. These occupations which will not be affected adversely by new technologies due to high education and/or skill levels that they possess are legislators, senior officials, and managers ( $1^{\text {st }}$ category); professionals $\left(2^{\text {nd }}\right.$ category), skilled agricultural and fishery workers ( $6^{\text {th }}$ category); and craft and related trades workers ( $7^{\text {th }}$ category).

However, a number of jobs and occupations from $3^{\text {rd }}$ (technicians and associate professionals), $4^{\text {th }}$ (clerks), $5^{\text {th }}$ (service workers, and shop and market sales workers), and $8^{\text {th }}$ (plant and machine operators and assemblers) categories might be affected adversely and thus easily substitutable by new technologies because the tasks that they perform are routine.

In the $3^{\text {rd }}$ category, only a limited number of occupations, namely science and engineering associate professionals, and information and communications technicians might be replaced by new technologies due to the routine tasks that these occupations require. On the other hand, health associate professionals, business and administration associate professionals, legal, social, cultural and related associate professionals will not be substituted by new technologies because these occupations require nonroutine and face-to-face tasks.

Most of the clerical occupations ( $4^{\text {th }}$ category) are susceptible to digitalization. Secretaries, keyboard operators, numerical clerks, material recording and transport clerks will be substituted by automation and digitalization, except the jobs that demand in-person interactions and situational adaptability. Some clerks are hired by central and local governments. For this reason, public policies need to be tackled very carefully because on one hand the state supports job generating initiatives which increase the amount of public clerks, on other hand the state adopts new technological improvements. Indeed digitalization is rapidly increasing in all public services that the government provides in Turkey (e-state).

Some of the service workers, and shop and sales workers ( $5^{\text {th }}$ category) will be substituted by digital technologies. Shopping via internet is gaining more access in Turkey. However, a considerable amount of occupations in this category requires high in-person interactions, such as personal services workers, sales workers, personal care workers, protective services workers. Therefore, some of these jobs will not be substituted but will be complemented by new technologies.

The category of plant and machine operators and assemblers $\left(8^{\text {th }}\right.$ 
category) is highly susceptible to robotization, automation, and digitalization. This does not mean that firms will fire all stationary plant and machine operators, assemblers, drivers and mobile plant operators, and substitute robots, automated machines, intelligent devices and vehicles with them. It is just a warning that the routine tasks can easily be substituted by new technologies and this might result in mass unemployment in that category.

Technological changes have always acted as employment destroyers and employment generators. In order to deal with the tsunami of new technologies, Turkey urgently needs a comprehensive project for analyzing, mapping, and policy designing of jobs and occupations that the Industry 4.0 might have positive and negative effects. Surveys, at least in the leading sectors, can be made about prospective technological capital investments in order to see the substituting and complementing effects of new technologies. Education and vocational training needs to be remodelled and upgraded by the efforts of governmental and non-governmental stakeholders. Some unique jobs which new technologies and creativity are extensively used (cultural and creative industries) can be promoted. Above all, flowing with change by care, caution, and wisdom will bring more wealth and peace to Turkey and to all.

\section{Acknowledgement}

Many thanks to Assoc. Prof. Dr. Başak Karpuz, DEU, Department of Mathematics, for his kind assistance.

\section{Endnote}

(1) After 2007, ILO replaced ISCO 88 by ISCO 08 which is a fourlevel hierarchically structured classification that allows all jobs in the world to be classified into 10 major groups, 43 sub-major groups, and 130 minor groups, based on their similarity in terms of the skill level and skill specialization required for the jobs. Turkey has rearranged the occupation categories according to ISCO 08 recently. However, due to the availability of data, the classification I used in this paper is based on ISCO 88, which is not very different from ISCO 08.

\section{References:}

1. Acemoglu, D. (1998). Why Do New Technologies Complement Skills? Directed Technical Change and Wage Inequality. The Quarterly Journal of Economics, Vol. 113, No. 4, pp. 1055-1089.

2. Acemoglu, D. (1999). Changes in Unemployment and Wage Inequality: An Alternative Theory and Some Evidence. The American Economic Review, Vol. 89, No. 5, pp. 1259-1278. 
3. Acemoglu, D. \& Autor, D. (2011). Skills, Tasks and Technologies: Implications for Employment and Earnings. Handbook of Labor Economics, Vol. 4(B), pp. 1043-1171.

4. Acemoglu, D. \& Autor, D. (2012). What Does Human Capital Do? A Review of Goldin and Katz's The Race between Education and Technology. Journal of Economic Literature, Vol. 50, No. 2, pp. 426463.

5. Autor, D. et al. (1998). Computing Inequality: Have Computers Changed the Labor Market?. The Quarterly Journal of Economics, Vol. 113 (November), pp. 1169-1213.

6. Autor, D. et al. (2003). The Skill Content of Recent Technological Change: An Empirical Exploration. The Quarterly Journal of Economics, Vol. 118, No. 4, pp. 1279-1333.

7. Autor, D. \& Dorn, D. (2009). This Job is "Getting Old": Measuring Changes in Job Opportunities using Occupational Age Structure. American Economic Review, Vol. 99, No. 2, pp. 45-51.

8. Autor, D. \& Dorn, D. (2013). The Growth of Low-Skill Service Jobs and the Polarization of the US Labor Market. American Economic Review, Vol. 103, No. 5, pp. 1553-1597.

9. Behaghel, L. et al. (2011). Information and Communication Technologies and Skill Upgrading: The Role of Internal vs. External Labour Markets. IZA Discussion Paper No: 549.

10. Ben-Ner, A. \& Urtasun, A. (2013). Computerization and Skill Bifurcation: The Role of Task Complexity in Creating Skill Gains and Losses. ILR Review, Vol. 66, No. 1, pp. 225-267.

11. Blinder, A. \& Krueger, A. (2013). Alternative Measures of Offshorability: A Survey Approach. Journal of Labor Economics, Vol. 31(S1), pp. S97 - S128.

12. Bresnahan, T.F. \& Greenstein, S. (1999). Technological Competition and the Structure of the Computer Industry. The Journal of Industrial Economics, Vol. 47, pp. 1-40.

13. Fonseca, T. et al. (2013). Technological change, routinization and job polarization: evidence from a middle-income country. Preliminary version paper, 1-26.

14. http://pascal.iseg.utl.pt/ leed2013/papers/PaperD2.pdf (16.11.2017)

15. Frey, C. B. \& Osborne, M. (2013). The Future of Employment: How Susceptible are Jobs to Computerization? University of Oxford Working Paper, published by Oxford Martin Programme on Technology and Employment, 1-72.

16. Givord, P. \& Maurin, E. (2004). Changes in job security and their causes: An empirical analysis for France, 1982-2002. European Economic Review, Vol. 48, pp. 595 - 615. 
17. Goos, M. et al. (2009). Job Polarization in Europe. American Economic Review, Vol. 99, No. 2, pp. 58-63.

18. Goos, M. et al. (2014). Explaining Job Polarization: Routine-Biased Technological Change and Offshoring. American Economic Review, Vol. 104, No. 8, pp. 2509- 2526.

19. Goldin, C. \& Katz, L. F. (2007). The Race Between Education and Technology: The Evolution of U.S. Educational Wage Differentials, 1890 to 2005. NBER Working paper series, 12984.

20. Nordhaus, W.D. (2007). Two Centuries of Productivity Growth in Computing. The Journal of Economic History, Vol. 67, No. 1, pp. 128-159.

21. Spitz-Oener, A. (2006). Technical Change, Job Tasks, and Rising Educational Demands: Looking outside the Wage Structure. Journal of Labor Economics, Vol. 24, No. 2, pp. 235-270.

22. Tinbergen, J. (1975). Income differences: recent research. Erasmus School of Economics, https://repub.eur.nl/pub/17616/ (24.09.2017).

23. McKinsey Global Institute (MGI) (2013). Disruptive technologies: Advances that will transform life, business, and the global economy. Technical Report.

24. The Boston Consulting Group (BCG) (2015). Man and Machine in Industry 4.0. Report.

25. Institute for Employment Research (IAB) (2016). Economy 4.0 and its labour market and economic impacts. Report. 